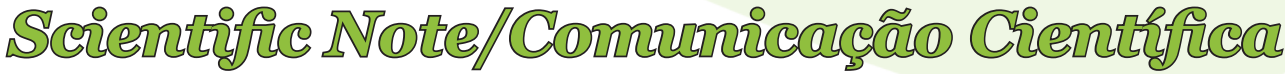

\section{Notes on Aethina tumida Murray (Coleoptera: Nitidulidae) in an apiary in the state of Rio de Janeiro}

\author{
Sérgio Nogueira Pereira1 ${ }^{\bowtie}$, Susana Gottschalk², Jorge Luiz T Palmeira1, Junio M Paulino', Rosa Maria Antunes ${ }^{1}$, \\ Roosevelt M A Boechat ${ }^{1}$, Virgínio Pereira da Silva Junior ${ }^{1}$, Paulo Henrique P de Moraes ${ }^{1}$, \\ Luis Henrique Soares Alves ${ }^{3}$ \& Fábio Prezoto 4
}

1. Secretaria de Estado de Agricultura, Pecuária, Pesca e Abastecimento do Rio de Janeiro (SEAPPA-RJ), Defesa Agropecuária, Coordenadoria de Defesa Sanitária Animal, Niterói, RJ, Brasil. 2. Ministério da Agricultura, Pecuária e Abastecimento, Superintendência Federal de Agricultura do Estado do Rio de Janeiro, Serviço de Inspeção e Sanidade Animal (SISA/SFA-RJ/MAPA), Rio de Janeiro, RJ, Brasil. 3. Centro de Ensino Superior de Valença (CESVA/FAA), Valença, RJ, Brasil. 4. Universidade Federal de Juiz de Fora (UFJF), Departamento de Zoologia, Laboratório de Ecologia Comportamental e Bioacústica (LABEC), Juiz de Fora, MG, Brasil.

\section{EntomoBrasilis 12 (2): 88-9o (2019)}

Abstract. We record, for the first time, the presence of Aethina tumida Murray (Coleoptera: Nitidulidae) in the Rio de Janeiro state, in an apiary constituted by 36 honeybee hives Apis mellifera L. No eggs or larvae of A. tumida were found, only adults. Since this is the second Brazilian state to record an infestation of small hive beetles, the responsible institutions and beekeepers on each federative unit must stay aware of this in order to prevent or retard their spreading.

Keywords: Africanized honeybees; Apis mellifera; Brazil; Small hive beetle; SHB.

\section{Notas sobre Aethina tumida Murray (Coleoptera: Nitidulidae) em apiário no estado do Rio de Janeiro}

Resumo. Foi notificada pela primeira vez a presença de Aethina tumida Murray (Coleoptera: Nitidulidade) no estado do Rio de Janeiro em um apiário formado por 36 colmeias de abelhas Apis mellifera L. Não foi constatado presença de ovos ou larvas de A. tumida, somente adultos. Por ser o segundo estado do país a relatar ocorrência de uma espécie exótica considerada uma praga em criações de abelhas do gênero Apis em outros países e por deter pouco conhecimento sobre o impacto desse invasor na apicultura nacional, os órgãos competentes em cada unidade federativa deverão ficar atentos e montar estratégias de prevenção e vigilância, a fim controlar e/ou erradicar $A$. tumida em solo brasileiro.

Palavras-chave: Abelhas africanizadas; Apis mellifera; Brasil; Pequeno Besouro das Colmeias; PBC.

$\mathrm{Te}$ oneybees are constantly affected by various parasites pests and pathogenic agents. In the Brazilian territory, Acariosis, Varoatosis, Nosemosis, American Sacbrood and Brazilian Sacbrood are usually found in Apis mellifera L. colonies. In 2015, the presence of Aethina tumida Murray (Small Hive Beetle: SHB) was detected for the first time in the state of São Paulo (TeIXeIra et al. 2016) and in South America (AL TOUfAILIA et al. 2017). The arrival of the SHB in Brazil was cause of concern for both the sanitary authorities and beekeepers, for the latter mainly due to beetles' capacity to cause severe losses to A. mellifera hives in North America, Australia, Europe and Asia (SPIEWOK \& NEUMANN 2006; GRECO et al. 2010; MUTINELli et al. 2014; CERVANCIA et al. 2016).

In Australia and the Philippines, SHBs were recorded infesting stingless bees (GRECO et al. 2010; CERvANCIA et al. 2016) and also bumblebees in North America (SPIEWOK \& NEUMANN 2006; HofFmanN et al. 2008). In Central America (Cuba), A. tumida infested colonies of Melipona beecheii Bennett (PEÑA et al.
2014). This data concerns Brazil deeply, since the country alone presents about 400 species of stingless bees (SILVA \& PAZ 2012), and we cannot predict how the native bees would respond to a SHB attack.

This communication aims to notify the scientific community, for the first time, the presence of $A$. tumida in the Rio de Janeiro state, as well as describe the epidemiological investigation of infected hives.

In October 2016, $A$. tumida specimens were found and captured in Apis mellifera hives in the capital of the Rio de Janeiro state by the official service of farming defense of the Secretaria de Estado de Agricultura, Pecuária, Pesca e Abastecimento do Rio de Janeiro (SEAPPA-RJ) along with the Ministério da Agricultura, Pecuária e Abastecimento (MAPA).

In an apiary containing 36 Langstroth hives infested by $A$. tumida (Figure 1), three colonies were arbitrarily chosen for the
Edited by:

William Costa Rodrigues

\section{Article History:}

Received: 07.xi.2018

Accepted: 10.iv.2019
Corresponding author:

Sérgio Nogueira Pereira

乃 spereirabio@gmail.com

(1) No ORCID record
Funding agencies:

$\leftrightarrow$ Without funding declared 


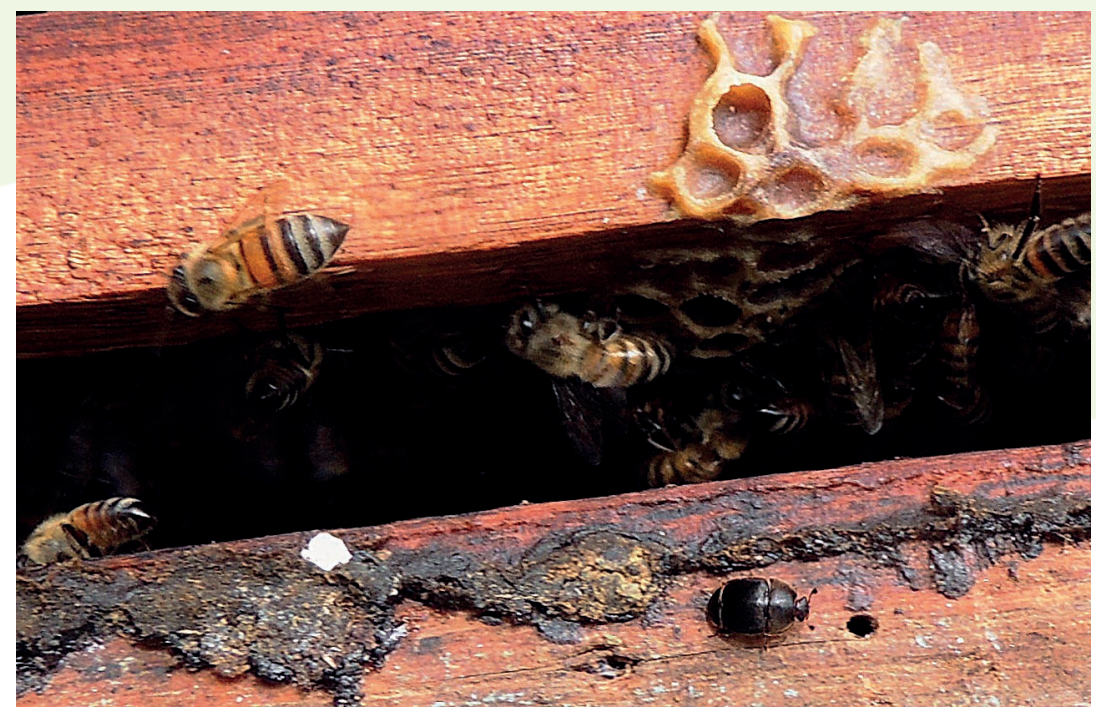

Figure 1. Aethina tumida Murray in the upper side of a Langstroth hive. Photo: JM Paulino.

biological material collection and behavior observations. The apiary is located at a slope with about $0.5 \mathrm{ha}$, within a permanent preservation area and approximately $30 \mathrm{~m}$ distant from a stream bed. The area is shaded by trees and bushes most of the day.

According to the beekeepers, the presence of the beetles in the hives had been observed for over one year and all hives were infested ever since. It was not possible to know how the SHBs appeared since the beekeeper reported that he hadn't purchased colonies or queens from suspicious localities. He informed still that he noticed the beetles during routine check-ups but did not give them importance since the bees performed their activities normally. When colonies were taken as healthy, shown by regular forager activity, the queen's egg-laying pattern was homogeneous, and so was the brood's distribution pattern. We must point out that the swarms in the apiary were being artificially fed with energetic and proteinaceous food. Search for larvae or pupae on the ground was not carried out, and the checking-ups were focused in collecting the adult beetles for later confirmation in the credentialed laboratory and the observation of interactions at the hive.

During the handling of approximately 30 minutes in every hive, it was possible to identify the defense behavior of bees towards the adult beetles. This consisted in successive attacks by workers during the beetles' movement in the hive. Such attacks, possibly consisting in biting, showed low success since the workers' advancements were hindered by the beetles' carapace and stance (by lowering their bodies and staying immobile), which prevented any damage the bees could cause. NeumanN et al. (2016) reported, for African honeybees, similar behavior to those described above; however, it was possible to observe injuries such as beheadings and/or the severing of the intruders' extremities. SHB eggs or larvae were not observed in any of the three analyzed colonies (cf. AL ToufaILIA et al. 2017).

Specimens of $A$. tumida were collected manually and through traps made of PVC plates (modified from SCHAFER et al. 2008), which were set in the bee entrance minutes before the hives were opened. After collection, the beetles were kept in individual tubes and traps were kept in hermetically closed plastic bags. All the biological material was kept in a freezer for 10 hours and then fixed in alcohol $70 \%$. This is an important measure since it prevents the escape and dispersion of adults from this exotic coleopteran species (TEIXEIRA et al. 2016). Part of the biological material was sent to the Instituto Biológico de São Paulo - Unidade Laboratorial de Referência em Fitossanidade - Laboratório de Entomologia Geral in order to confirmation of the species.
As a preventive measure to avoid the spreading of the SHB, the apiary was interdicted by SEAPPA-RJ. Among the epidemiologic vigilance measures taken, it was established that: 1) every registered or unregistered apiary and meliponary in the metropolitan area of Rio de Janeiro should be inspected; 2) every suspicious report should be seen to, regardless of its location in the state; 3) talks and technical meetings should be carried out among beekeeper associations, rural syndicates, city councils and other similar institutions in order to expose the problem and search for supporting partnerships; 4) technical teams should be trained to act in new focuses, if needed, and 5) registering and re-registering of apicultures and meliponicultures should be carried out.

By confirming the presence of $A$. tumida, this communication is the first record of such pest in the Rio de Janeiro state. We highlight that the species distribution area is increasing in Southeastern Brazil, and there is a possibility of spreading to pest-free areas. Facing this evidence, the responsible institutions within each state must be cautious on the matter and adopt measures of prevention, surveillance, monitoring, control and/or eradication of A. tumida, ensuring the decrease of losses caused by this pest which is, until then, poorly known by Brazilian beekeepers.

\section{REFERENCES}

Al Toufailia, H, DA Alves, DC Bená, JMS Bento, NSA Iwanicki, AR Cline, JD Ellis \& FLW Ratnieks, 2017. First record of small hive beetle Aethina tumida Murray, in South America. Journal Apicultural Research, 561: 76-80. DOI: https://doi.org/10.1080/00218839.2017.1284476.

Cervancia, CR, LI Guzman, EA Polintan, ALB Dupo \& AA Locsin, 2016. Current status of small hive beetle infestation in the Philippines. Journal Apicultural Research, 55: 74-78. DOI: https://doi.org/10.1080/00218839.2016.1194053.

Greco, MK, D Hoffmann, A Dollin, M Duncan, RSpooner-Hart \& P Neumann, 2010. The alternative Pharaoh approach: stingless bees mummify beetle parasites alive. Naturwissenschaften, 97: 319-323. DOI: https://doi.org/10.1007/s00114-0090631-9.

Hoffmann, D, JS Pettis \& P Neumann, 2008. Potential host shift of the small hive beetle (Aethina tumida) to bumblebee colonies (Bombus impatiens). Insectes Sociaux, 55: 153-162. DOI: https://doi.org/10.1007/s00040-008-0982-9.

Mutinelli, F, F Montarsi, G Federico, A Granato, AM Ponti, G Grandinetti, N Ferrè, S Franco, V Duquesne, M-P Rivière, R Thiéry, P Henrikx, M Ribière-Chabert \& M-P Chauzat, 2014. Detection of Aethina tumida Murray (Coleoptera: Nitidulidae) in Italy: out breaks and early reaction 
measures. Journal Apicultural Research, 53: 569-575. DOI: https://doi.org/10.3896/ibra.1.53.5.13.

Neumann, P, JS Pettis \& MO Schäfer, 2016. Quo vadis Aethina tumida? Biology and control of small hive beetles. Apidologie 47: 1-40. DOI: https://doi.org/10.1007/s13592-016-0426-x.

Peña, WL, LF Carballo \& JD Lorenzo, 2014. Reporte de Aethina tumida Murray (Coleoptera, Nitidulidae) en colonias de La abeja sin aguijón Melipona beecheii Bennett de Matanzas y Mayabeque. Revista Salud Animal, 36: 201-204.

Schafer, MO, J Pettis, W Ritter \& P Neumann, 2008. A scientific note on Quantitative diagnosis of small hive beetles, Aethina tumida, in the field. Apidologie, 39: 564-565. DOI: https://doi.org/10.1051/apido:2008038.
Silva, WP \& JRL Paz, 2012. Abelhas sem ferrão: muito mais do que uma importância econômica. Natureza on line, 10: 146152. Available in: <http://www.naturezaonline.com.br $>$.

Spiewok, S \& P Neumann, 2006. Infestation of commercial bumblebee (Bombus impatiens) field colonies by small hive beetles (Aethina tumida). Ecological Entomology, 31: 623-628. DOI: https://doi.org/10.1111/j.13652311.2006.00827.x.

Teixeira, EW, D Jong, A Sattler \& D Message, 2016. Aethina tumida Murray (Coleoptera, Nitidulidae), o pequeno besouro das colmeias, chega ao Brasil. Mensagem Doce, APACAME. 136.

$* * * * * * * * * *$

\section{Suggestion citation:}

Pereira, SN, S Gottschalk, JLT Palmeira, JM Paulino, RM Antunes, RMA Boechat, VP Silva Junior, PHP Moraes, LHS Alves \& F Prezoto, 2019. Notes on Aethina tumida Murray (Coleoptera: Nitidulidae) in an apiary in the state of Rio de Janeiro. EntomoBrasilis, 12 (2): 88-90.

Available on: doi:10.12741/ebrasilis.v12i2.824

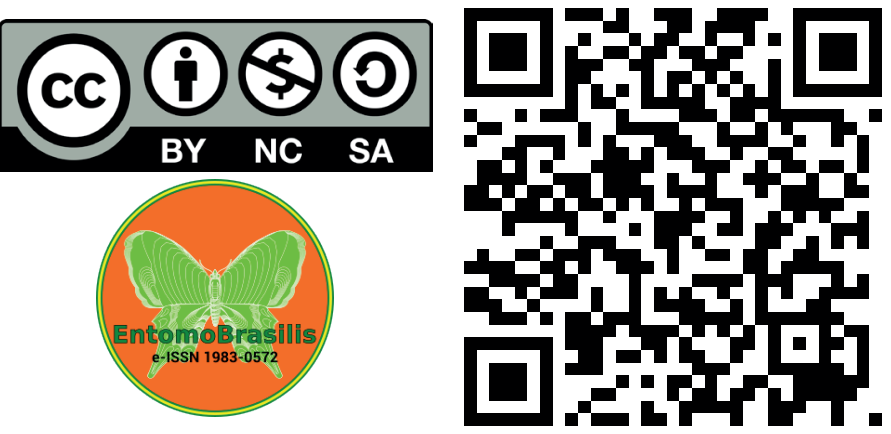

